\section{AL-AZHAR}

Assiut Dental Journal
The Official Publication of The

Faculty of Dental medicine.

Al-Azhar Assiut Uniuersity.

Egypt

AADJ, Vol. 3, No. 1, April (2020) - PP. 33:42

ISSn 2682-2822

\title{
Immediate Placement of Dental Implant with Ridge Augmentation Using Autogenous Bone Ring Transplant
}

\author{
Ahmed H. Abdel-wahab* , Bahaa El-Din A. Tawfik *
}

Codex : 05/2020/04

Aadj@azhar.edu.eg

\section{KEYWORDS}

Autogenous Chin Bone Ring,

Defective Sockets,

Augmentation Technique, CBCT,

Simultaneous Implant Placement

1. Department of Oral and Maxillofacial surgery, Faculty of Dental Medicine (Boys), Cairo, Al-Azhar University, Egypt.

* Corresponding Author e-mail: dr.ahmedhegazy.stu.p.9@ azhar.edu.eg

\begin{abstract}
Aim: This study was designed to evaluate autogenous chin bone ring consolidation after the augmentation of severely defective sockets and the clinical application of these rings in the premolar-molar region with simultaneous implant placement in a one-stage procedure. Subjects and Methods: Ten patients were selected from those attending the outpatient clinic of the Department of Oral and Maxillofacial Surgery, Faculty of Dental Medicine, Boys, Cairo, Al Azhar University. All selected patients had fresh defective extraction sockets in the mandibular premolar molar region with severely compromised buccal bone. Clinical examination was made to all patients as: Quality, quantity of the bone, mucosa, contour of the underlying bone. Preoperative cone beam CT was taken for every patient to determine alveolar bone height\& width. The change in the implant stability and bone density was measured using cone beam computerized tomography (CBCT) immediately, and after 6 months of healing. All readings were recorded and evaluated statistically. Results: The difference between crestal bone height immediate and six months postoperatively was statistically significant in buccal and lingual surface ( $\mathrm{p}$ value $=0.001)$, $(\mathrm{p}$ value $=0.000$ ) respectively. While was not statistically significant in mesial and distal surface ( $\mathrm{p}$ value $=0.068$ ), $(\mathrm{p}$ value $=0.960)$ respectively. Conclusion: The autogenous chin bone ring augmentation technique was found to be a reliable alternative method for the management of severely defective sockets.
\end{abstract}

\section{INTRODUCTION}

Defective sockets resulting from either periodontal disease or surgical trauma during extraction may have an insufficient quantity of bone for successful implant placement. Several classifications of post-extraction sockets in relation to immediate implant placement have been reviewed in the literature; Salama and Salama have classified extraction sockets. Into four classes according to the degree of severity of the buccal wall defects ${ }^{(1)}$.

A number of techniques have been described for the augmentation of defective sockets for implant placement either in a simultaneous 
approach or a consecutive approach. These include socket preserva- tion, guided bone regeneration, and localized horizontal ridge augmentation using titanium mesh and onlay bone grafting ${ }^{(2-6)}$. Socket preservation and guided bone regeneration have shown successful results in immediate implant placement for class I and class II sockets of the Salama classification $^{(7)}$. However, sockets of class III and class IV are severely compromised, with partial or total loss of the buccal plate of bone, and implant placement within the remaining bone would result in a significantly off-axis implant position. In such cases, immediate bone grafting with delayed implant placement has been necessary to solve this problem.

a) B.D.S, 2019 G, Faculty of Dental Medicine, Boys, Cairo Al-Azhar University, Dentist, Ministry of Health.

b) Assistant Professor, department of Oral and Maxillofacial Surgery, Faculty of Dental Medicine, Boys, Cairo Al-Azhar University.

Autogenous corticocancellous chin bone grafts, either in the form of blocks or particulates, have been used successfully for the augmentation of localized alveolar defects. There is experimental evidence that intramembranous bone grafts undergo less resorption than endochondral grafts when used in an onlay technique, based on the more rapid revascularization and similar embryonic origin (ectomesenchyme) of the donor and recipient sites, which enhance early healing ${ }^{(8-10)}$. Several studies have reported the use of a trephine bur in the chin region for ridge augmentation. These have shown excellent results in relation to implant success and survival rates, with minor complications in terms of damage to the local anatomical structures such as the teeth, nerves, muscles, and vasculature and infection in the donor site area. It has also been stated that incisions in the labial vestibule rather than a sulcular approach allows preservation of the crestal bone and a more secure closure with reapproximation of the mentalis muscle, resulting in a lower risk of chin $\operatorname{ptosis}^{(11-18)}$.
The chin bone disc was first introduced to the surgical field by Watzak et al. for the bony closure of oro-antral fistulas ${ }^{(19)}$. The chin bone disc was recently modified to a ring shape for the three-dimensional augmentation of defective sockets in the maxillary incisor region with simultaneous implant placement; this technique proved successful in bone augmentation and implant integration ${ }^{(20-22)}$.

\section{AIM OF THE STUDY}

The aim of the present study was to evaluate the immediate placement of dental implant with ridge augmentation using an autogenous bone ring transplant.

\section{PATIENT AND METHODS}

\section{Inclusion and exclusion criteria}

A prospective study was conducted on a consecutive series of 10 patients. All selected patients had fresh defective extrac- tion sockets in the mandibular premolar- molar region in which the buccal bone was severely compromised and implant placement within the remaining bone would have resulted in a significantly off-axis implant position. The alveolar bone sur- rounding the extraction sockets was defective either due to periodontal disease or traumatic extraction.

Patients with any systemic disease that could affect bone healing were excluded from the study.

\section{Materials}

Implant (Two-stage screw Biomate Implant System ) is mounted on a color-coded fixure mount, designed for use as a transfer, or shortened for use as a straight abutment.

The trephine burs utilized in this study were supplied with diameters $6.0 \mathrm{~mm}, 7.0 \mathrm{~mm}, 8.0 \mathrm{~mm}, 9.0$ $\mathrm{mm}$, and $10.0 \mathrm{~mm}$ (Dentium Co., Ltd, Gyeonggido, Korea). 


\section{A -Preoperative phase}

All patients underwent pre-operative clinical examination: Patients' data were collected; name, gender and age, medical and dental histories were taken and the oral mucosa of the edentulous area was examined by inspection and palpation. Also, all patients underwent standardized periapical radiography to detect any periapical pathology and a pre-operative CBCT to select the proper size of the implants to be installed and The linear measurement of the chin area as a donor site, to determine the area from which the graft could be harvested to coincide with the socket

\section{B -Operative phase}

All patients were instructed to rinse with chlorhexidine mouth wash (Listermix plus, SIGMA Pharmaceutical Industries, Egypt) immediately before operation for 2 minutes.

All patients were treated using local anesthesia, articaine HCL and epinephrine 1:20.000 (Septodont, by Novocol Pharmaceutical of Canada, Inc.)

\section{Bone rings harvesting:}

The symphysis was accessed through a vestibular incision. The mental nerves were protected. Using trephine bur and under copious saline irrigation, circular osteotomies were outlined (monocortically), the size of trephine bur determine by preoperative clinical and CBCT assessment of tooth to be extracted and preoperative plane of ridge augmentation and the selected implant diameter and length. The bone discs outline were placed 3-4 mm away from the root apices of the mandibular anterior teeth. In the center of the chin disc, an implant osteotomy was performed using successive drills corresponding to the final implant diameter to be placed in the center of each disc converting it to a "bone ring." with preservation of at least $2 \mathrm{~mm}$ of normal intact bone around the implant osteotomy. The harvesting of the bone ring was then completed to its definitive depth using the same trephine bur that outlined it.
The "bone rings" were then carefully removed from the chin. The ring was either completely pulled out of its place simultaneously inside the trephine bur during its withdrawal or removed by the aid curette. The ring was then kept in normal saline and pack of gauze was placed in donor site till debridement, irrigation and closure of the donor site.

\section{Implant surgery:}

The socket was prepared by using a trephine bur of a diameter sequentially smaller than the used for graft harvesting.

Preparation of the socket was performed guided by the preoperative plane of ridge augmentation and the selected implant diameter and length.

The bone ring was then tapped into the prepared socket augmenting it three dimensionally (vertically and horizontally) and to be $1-2 \mathrm{~mm}$ above the adjacent socket walls to compensate for the anticipated bone resorption. Once the bone graft had been inserted, the implant drill was used to prepare the apical basal bone of the socket for at least three millimeters through the central osteotomy of the ring. Implants were then screwed through the bone rings and basal alveolar bone. Finally, the covering screw was secured and periosteal scoring was then accomplished at the base of the flap to advance and expand the soft tissues and provide primary closure without tension.

\section{C-Postoperative phase}

After closure of the wound, a pressure band was applied to the chin and cheek areas for $48 \mathrm{~h}$ postoperatively. The patients were then instructed to apply ice-packs over the chin and cheek area for $20 \mathrm{~min}$ every hour for $6 \mathrm{~h}$ postopera- tively and to rinse their mouth with warm saline solution starting on the second day after surgery, three times per day during the first week postoperative. The patients were kept on a soft diet for the first $48 \mathrm{~h}$. Amoxicillin $875 \mathrm{mg} /$ claviulanic acid $125 \mathrm{mg}$ antibiotic 


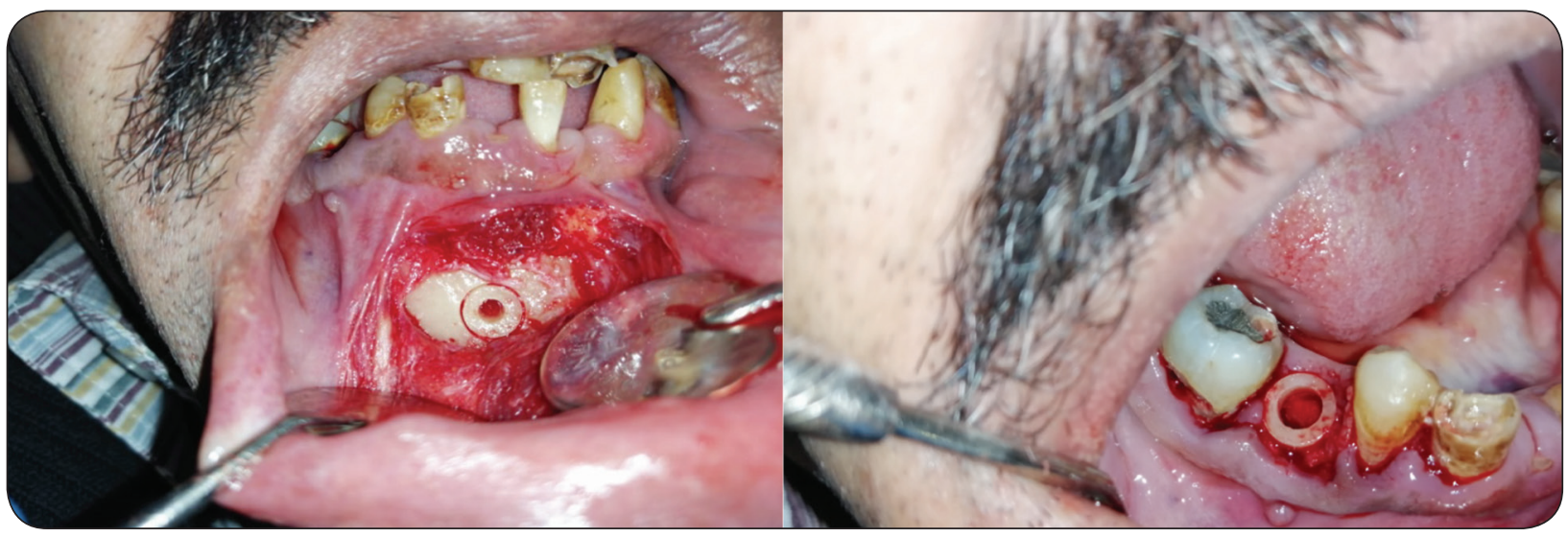

Fig. (1) (A and B) photograph showing bone ring after preparation centeral osteotomy by implant drills(A) and placement of the bone ring in recipient site $(\mathrm{B})$.

tablet (Augmentin $1 \mathrm{gm}$, Glaxosmithkline, Australia), one tablet every 12 hours for 5 days postoperatively. Diclofenac sodium non-steroidal antiinflammatory drugs $50 \mathrm{mg}$ tabs (Cataflam, Novartis pharma, Basel, Switzerland) one tablet every 8 hours for five days. Chymotrypsin + trypsin ${ }^{\circledR}$ tablets (Alphintern, Kahira. pharm \& chem. Ind. co., Cairo, Egypt), was administrated half an hour before meals 3 times for 7 days.

\section{D- Follow up phase}

\section{Clinical evaluation}

Early follow up was performed daily for the first week after implant placement, then weekly for the first month for any signs of infection, pain, swelling or any post-operative complications.

\section{Patients were evaluated clinically for:}

Suture breakdown, dehiscence both the donor and the recipient sites and implant or graft exposure.

Checking for presence or absence of pain, numbness, swelling, infection, hematoma and bleeding at both donor and recipient sites.

Measurement of implant secondary stability was performed by Osstell ${ }^{\mathrm{TM}}$.immediately and after 6 months from implant placement.

\section{Radiographic evaluation:-}

All implants involved in this study were followed up radiographically by Cone beam computed tomography (CBCT) to evaluate crestal bone loss around implant.It was done immediately after implant placement and after 6 months.

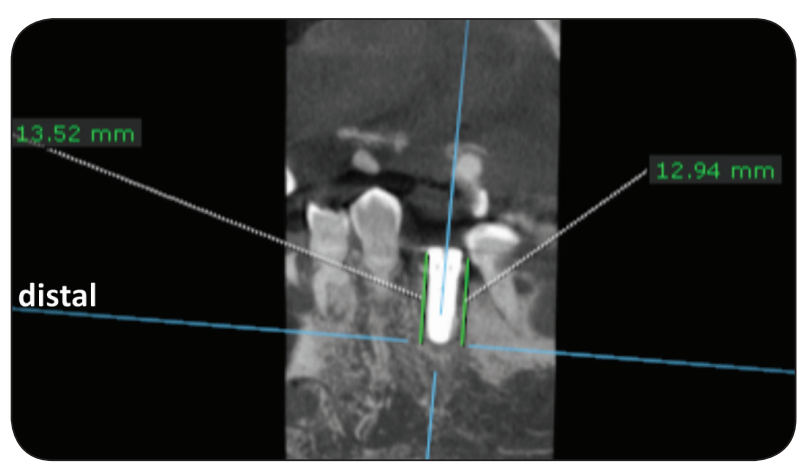

Fig. (2) Immediate postoperative assessment, coronal cut showing height measurement both mesial and distal aspect.

\section{Statistical analysis:}

Data were represented as mean and standard deviation. Repeated measures analysis of variance (ANOVA) test was used to compare numeric variables within the studied group of patients. Post Hoc test was done if ANOVA or Friedman tests were positive. Using SPSS version in all tests, result was considered statistically significant if the p-value was less than 0.05 . 


\section{RESULTS}

A total of 10 patients (7 males and 3 females) with average age of 35.30 (range 24-49 years) with insufficient vertical alveolar ridge in mandibular posterior teeth were selected from the outpatient clinic of the Department of Oral and Maxillofacial Surgery, Faculty of Dental Medicine, Boys, Cairo, Al Azhar University. The selected patients were collectively having four premolars and six molars. A total of ten chin bone rings were harvested with immediate implants placement in one stage procedure, and then evaluated clinically and radiographically using CBCT.

All patients underwent surgery in local anesthesia and no complications had been recorded during the operation.

\section{Clinical results:}

All patients had been examined periodically during the follow-up period up to 6 months. Healing was uneventful in all cases with no post-operative complications.

\section{Donor site findings:}

A total of ten rings were harvested from mandibular symphyseal region using trephine bur. Four rings were passively pulled out of their place simultaneously with trephine bur withdrawal. Six rings were not withdrawal with trephine bur necessitating their removal by aid of surgical curette.. Two rings were eight millimeters in diameter with $4.1 \mathrm{~mm}$ central osteotomy. Eight rings were seven millimeters in diameter with $3.7 \mathrm{~mm}$ central osteotomy. With average length of $4-6 \mathrm{~mm}$.

Wound healing was uneventful in all patients with no signs of infection, dehiscence, bleeding. Mild postoperative edema was noticed in all patients, which spontaneously resolved within one week postoperatively. Three patients suffered from transient numbness in lower lip and gingiva of lower anterior teeth which spontaneously disappeared within one month postoperatively (case no. 3, 5, and 8).

\section{Recipient site findings}

\section{Intraoperative findings:}

The harvested bone rings were snuggly fitted in the extraction sockets. Minor contour adjustments were necessary to ensure their adaptation and stability. The implants were then installed passively through the bone rings, achieving the primary stability from basal alveolar bone. All implant-ring complexes did not show any degree of mobility at the end of implant installation.

\section{Postoperative findings:}

Wound healing was uneventful in all patients with no signs of infection, bleeding, or wound dehiscence except in two cases that showed graft dehiscent within first week postoperatively (case no.2\&5). (Fig. 31). These two cases were managed by smoothening the sharp edges and reducing the overcontour of bone rings, followed up by chlorhexidine mouth wash and daily irrigation, case no.2 healed spontaneously by secondary intention while other case (case no.5) closed surgically three months postoperatively.

Implant stability evaluation; Osstell is used to measure implant stability and bone density by vibration and structural analysis (Radio Frequency analysis) RFA. Osstell has a computerized analysis and a measurement unit (Implant Stability Quotient) ISQ is from 0 to 100 , the successful implant is more than 65 and failure is considered less than 50 Immediately after implant insertion, the mean value of implant stability quotient (ISQ) was $49.00 \pm 4.97$, while after 6 months The mean (ISQ) was 71.70 \pm 5.12 . Table(2)

\section{Radiographic evaluation}

All patients had been examined radiographically using Cone beam computed tomography (CBCT) it was done to evaluate Alveolar crestal bone loss and bone density around the implants during the follow 
up periods: The difference between crestal bone height immediate and six months postoperatively was statistically significant in buccal and lingual surface ( $\mathrm{p}$ value $=0.001)$, $(\mathrm{p}$ value $=0.000$ ) respectively. While was not statistically significant in mesial and distal surface ( $\mathrm{p}$ value $=0.068)$, $(\mathrm{p}$ value $=0.960$ ) respectively.

Table (1): Difference in Implant stability by Osstell (ISQ) during the follow up periods .

\begin{tabular}{|c|c|c|c|c|c|c|}
\hline \multicolumn{2}{|c|}{} & $\begin{array}{c}\text { Immediate post } \\
\text { operative }\end{array}$ & $\begin{array}{c}6 \text { months post } \\
\text { operative }\end{array}$ & Test value* & P value & Sig. \\
\hline \multirow{3}{*}{ Stability } & Mean \pm SD & $49.00 \pm 4.97$ & $71.70 \pm 5.12$ & -15.22 & 0.000 & HS \\
\cline { 2 - 7 } & Range & $43-57$ & $64-80$ & & & \\
\hline
\end{tabular}

\section{DISCUSSION}

The replacement of the teeth with dental implants has become an effective modality, their predictability relies on the successful osseointegration during the healing period ${ }^{(23)}$. Salama and Salama classified the defective sockets into three types. According to them, type I defects can be managed using the principles of guided tissue regeneration (GTR). Type II defects can either be converted to type I defects using orthodontic extrusive augmentation or by GTR alone when orthodontic extrusive augmentation is not possible. Both type I and II defects are suitable for immediate implantation. However, type III defects are severely compromised and immediate implant placement is usually not possible. In such cases, a two-step approach is used. The first step is the augmentation procedure while the second step is the actual implant placement ${ }^{(1)}$.

However, to reduce the overall treatment time and difficulties in the management of severely defective sockets, a new technique was introduced by Stevens et al. to augment the defective socket three-dimensionally with autologous "bone rings" and immediate implant placement in a one-stage procedure $^{(20)}$.

Mandibular Symphyseal bone contains more cancellous bone than other intraoral sites, thus providing a greater amount of osteoprogenitor cells ${ }^{(24)}$. It had been utilized universally for intraoral aug- mentation up to $6 \mathrm{~mm}$ in horizontal and vertical dimensions. In addition, the intraoral grafts derived from intramembranous bone have less resorption than the grafts derived from endochondral bones like the iliac crest, fibula, and tibia ${ }^{(25,26)}$.

In the current study of a one-stage approach, the implant and vertical ridge augmentation were complete simultaneously. The major advantage of a onestage procedure, in addition to the lower number of surgical interventions required and reduced overall healing time, is that the bone graft stabilization is provided with implants ${ }^{(27)}$. Generally, the single-stage approach has proven to be safe and effective. Lekholm et al reported that a two stage approach provides higher success rates than a one-stage approach. However, if primary implant-graft stability is achieved during surgery; the one stage procedure can be successful as two stage procedure ${ }^{(21)}$. the result of current study proven successful of one stage procedure.

Dimension of the graft ring was determined using the exact dimension of the socket and the implant to be placed. Outer diameter of the ring should match the dimension of the socket and inner diameter should match the diameter of the implant. Further, recipient site was prepared using a trephine bur to accommodate the graft with a snug fit. This provided for the absolute stability of the implant bone ring complex which was essential for the early healing and decreased resorption of the graft $^{(28)}$. 
There are several advantages proposed by this technique, including a 3D augmentation of the native alveolar ridge, elimination of the socket gap implants interface, and the ability to provide additional stability of the implant at the crestal region of the implant. The additional stability is achieved through screwing the implants to the bone rings, which are tailored to fit snuggly into the socket walls. The simultaneous onlay crestal augmentation by the "bone rings" at the residual socket also enhances the soft tissue contour and helps resist soft tissue contraction in this highly esthetic zone ${ }^{(20)}$.

In the current study; Wound healing at recipient site was uneventful in all patients with no signs of infection, bleeding, or wound dehiscence except in two cases that showed graft dehiscent within first week postoperatively (case no.2\&5). This is most properly due to the sharp edges and overcontour of bone rings, these two cases were managed by smoothening the sharp edges of bone rings and reduced the overcontour, followed up by chlorhexidine mouth wash and daily irrigation, case no. 2 healed spontaneously by secondary intention while other case (case no.5) closed surgically three months postoperatively.

Wound healing at donor site was uneventful in all patients with no signs of infection, dehiscence, bleeding. Mild postoperative edema was notice in all patients, which spontaneously resolved within one week postoperatively. The most likely reason for the edema is in/lammatory response to tissue trauma. three patients (case no. 3,5, and 8) suffered from transient numbness in lower lip and gingiva of lower anterior teeth which spontaneously disappeared within two months postoperauvely, The most likely reason for the numbness is due to neuropraxia of the incisive nerve or the terminal branches of the mental nerve, which result as consequence of retraction of flap during operation and/or postoperative edema compression.

At the time of insertion, all implants bone ring complex showed adequate primary stability as mea- sured clinically. Thus, the basic criteria for success of immediate implants and successful grafting were being fulfilled ${ }^{(114)}$.

All implants in the present study were successful with primery and secondary stability assessed with resonance frequency analysis. The mean of primary implant stability was $49.00 \pm 4.97$, while after six months increased to $71.70 \pm 5.12$.

The result showed that; the difference between crestal bone height immediate and six months postoperatively was statistically significant in buccal and lingual surface ( $\mathrm{p}$ value $=0.001)$, $(\mathrm{p}$ value $=0.000)$ respectively. While was not statistically significant in mesial and distal surface ( $\mathrm{p}$ value $=$ $0.068)$, $(\mathrm{p}$ value $=0.960$ ) respectively.

These findings are in general agreement with those of other study; Omara $\mathrm{M}$ et $\mathrm{al}^{(29)}$ assessed clinical and radiographical outcome of chin bone ring graft with immediate implant placement in fresh extraction socket of mandibular premolar and molar teeth in one stage procedure, who found that the average mean of crestal bone resorption $=0.26$, while did not agreement with a study conducted by Crespi et al. study ${ }^{(30)}$ who demonstrated that after a 24-month follow-up, mean mesial and distal bone loss were $1.16 \pm 0.32 \mathrm{~mm}$ and $1.17 \pm 0.41 \mathrm{~mm}$, respectively.

\section{CONCLUSIONS}

This study concluded that Bone ring augmentation technique is an effective alternative option in reducing the treatment duration for implants placed in extremely defective sockets.

Patient selection and primary stability of implant bone ring complex play a crucial role in the success of bone ring implants, so long implant should be used to crossing apical bone to establishing primary stability. Thus, we recommended at least $3 \mathrm{~mm}$ of healthy bone beyond the apex. 
Tension-free closure and rounded margins of ring graft are important to prevent any soft tissue dehiscence at recipient site.

\section{REFERENCES}

1. Salama H, Salama M. The role of orthodon- tic extrusive remodeling in the enhancement of soft and hard tissue profiles prior to implant placement: a systematic approach to the management of extraction site defects. Int $J$ Periodontics Restorative Dent 1993;13: 312-33.

2. Kaufman E, Wang PD. Localized vertical maxillary ridge augmentation using symphy- seal bone cores: a technique and case report. Int J Oral Maxillofac Implants 2003;18: 293-8.

3. Cordaro L, Amande DS, Cordaro M. Clinical results of alveolar ridge augmentation with mandibular block bone grafts in partially edentulous patients prior to implant place- ment. Clin Oral Implants Res 2002;13: 103-11.

4. Buser D, Dula K, Hirt HP, Schenk RK. Lateral ridge augmentation using autograft and barrier membranes: a clinical study with 40 partially edentulous patients. J Oral Max- illofac Surg 1996;54:420-32.

5. Basa S, Varol A, Turker N. Alternative bone expansion technique for immediate implant placement of implants in the edentulous posterior mandibular ridge: a clinical report. Int J Oral Maxillofac Implants 2004;19: 554-8.

6. Khamees J, Darwiche MA, Kochaji N. Al- veolar ridge augmentation using chin bone graft, bovine bone mineral, and titanium mesh: clinical, histological, and histomorphometric study. J Indian Soc Periodontol 2012;16:23540 .

7. Irinakis $\mathrm{T}$, Perio D. Rationale for socket preservation after extraction of a single-root- ed tooth when planning for future implant placement. J Can Dent Assoc 2006;72: 917-22.

8. Jensen J, Sindet-Pedersen S. Autogenous mandibular bone grafts and osseointegrated implants for reconstruction of the severely atrophied maxilla. J Oral Maxillofac Surg 1991;49:1277-87.

9. Koole R, Bosker H, van der Dussen FN. Secondary autogenous bone grafting in cleft patients comparing mandibular (ectomesenchymal) and crista iliaca (mesenchymal) grafts. J Craniomaxillofac Surg 1989;17(Suppl. 1):28-30
10. Koole R. Ectomesenchymal mandibular symphysis bone graft: an improvement in alveolar cleft grafting. Cleft Palate Cranio-fac J 1994;31:217-23.

11. Deatherage J. Bone materials available for alveolar grafting Oral Maxillofac surg Am 2010;22:347-52.

12. Cordaro L, Torsello F, Miuccio MT, Mirisola di Torresanto $\mathrm{V}$, Eliopoulos D. Mandibular bone harvesting for alveolar reconstruction and implant placement: subjective and objective cross-sectional evaluation of donor and recipient site up to 4 years. Clin Oral Implants Res 2011;22:1320-6.

13. Montazem A, Valauri V, Hilaire H, Buch- binder D. The mandibular symphysis as a donor site in maxillofacial bone grafting: a quantitative anatomic study. J Oral Maxillo- fac Surg 2000;58:1368-71.

14. Gapski R, Wang HL, Misch CE. Manage- ment of incision design in symphysis graft procedures: a review of the literature. J Oral Implantol 2001;27:134-42.

15. Weibull L, Widmark G, Ivanoff CJ, Borg E, Rasmusson L. Morbidity after chin bone harvesting - a retrospective long term fol- low-up study. Clin Implant Dent Relat Res 2009;11:149-57.

16. Chaushu G, Blinder D, Taicher S, Chaushu S. The effect of precise reattachment of the mentalis muscle on the soft tissue response to genioplasty. J Oral Maxillofac Surg 2001;59:510-6.

17. Calvero J, Lundgren S. Ramus or chin grafts for maxillary sinus inlay and local onlay augmentation: comparison of donor site morbidity and complications. Clin Implant Dent Relat Res 2003;5:154-60.

18. Pikos MA. Mandibular block autografts for alveolar ridge augmentation. Atlas Oral Maxillofac Surg Clin North Am 2005;13: 91-107.

19. Watzak G, Tepper G, Zechner W, Monov G, Busenlechner D, Watzek G. Bony press-fit closure of oro-antral fistulas: a technique for pre-sinus lift repair and secondary closure. J Oral Maxillofac Surg 2005;63:1288-94.

20. Stevens MR, Emam HA, El Alaily M, Shar- awy M.Implant bone rings. One-stage three- dimensional bone transplant technique: a case report. J Oral Implantol 2010;1:69-74.

21. Giesenhagen B, Yü ksel O. Einzeitig behan- deln mit Knochenringen. VertikaleAugmen- tation und Implantation in nur einem Eingriff. Implantol J 2010;14:50-2.

22. Kielhorn J, Roland B. Improved guided bone ring technique: a case report. EDI J 2011;1:42-3. 
23. Quirynen M, Van Assche N, Botticelli D, Berglundh T. How does the timing of implant placement to extraction affect outcome? Int J Oral Maxillofac Implants 2007;22:203-23.

24. Herford A S. and Dean J S, Complications in bone grafting. Oral Maxillofac Surg Clin North Am, 2011; 23: 433-42.

25. Pikos M A, Mandibular block autografts for alveolar ridge augmentation. Atlas Oral Maxillofac Surg Clin North Am, 2005; $13: 91-107$.

26. Rosenthal A H, and Buchman S R, Volume maintenance of inlay bone grafts in the craniofacial skeleton. Plast Reconstr Surg, 2003; 112 : 802-11.

27. Tekin U, Kocyigit D I , and Sahin V , Symphyseal bone cylinders tapping with the dental implant into insufficiency bone situated esthetic area at one-stage surgery: a case report and the description of the new technique. J Oral Imp, 2010; 37: 589-94.

28. Phillips JH, Rahn BA. Fixation effects on membranous and endochondral onlay bone-graft resorption. Plast Reconstr Surg. 1988;82:872.

29. Omara M, Abdelwahed N, Ahmed M, Hindy M. Simultaneous implant placement with ridge augmentation using an autogenous bone ring transplant. Int J Oral Maxillofac Surg. 2016 ;45:535-44.

30. Crespi R, Capparé P, Gherlone E, Romanos GE. Immediate versus delayed loading of dental implants placed in fresh extraction sockets in the maxillary esthetic zone: A clinical comparative study. Int J Oral Maxillofac Imp. 2008;23:753-8. 


\author{
الأjز \\ مجلة أسيوط لطب الأسنان
}

النشر الرسمي لكلية طب الأسنان جامعة الأزهر أسيوط الكانة

\section{وضع غرسة سنية فورية بالتزامن مع ترقيع الحفرة النسخية بإستخدام طعم عظمي أسطواني الشكل من منطقة الذّة الذقن}

\section{احمد حجازى عبدالوهاب* ، بهاء الدين عبدربه توفيق}

1. قسـم جراحة الفه والوجه والفكين، كلية طب الاسنان (بنين ( ،القاهرة، جامعة الأزهر ، جهمهورية مصر العربية

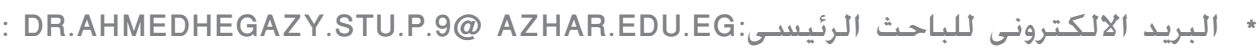

الملخص:

الهدف: الهدف من هذه الدراسة هو تقيبم النتائج السريرية والشعاعية لعملية الترقيع الثلاثية الأبعاد للحفرة النسخية المعيبة باستخدام طعم عظهي أسطواني الشكل من منطقة الذقن في الضروس الخلفية السفلية بالتزامن مع وضع غرسة سنية فورية في مرحلة واحدة. المواد والاساليب :شملت الدراسة عشرة مرضى لديهم ارتفاع سنخي غير كافي في الضروس الخلفية السفلية. وقد تراوحت أعمارهم بين

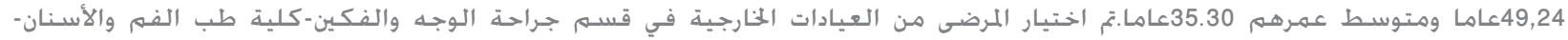

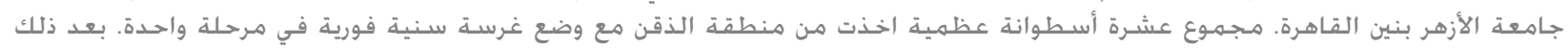

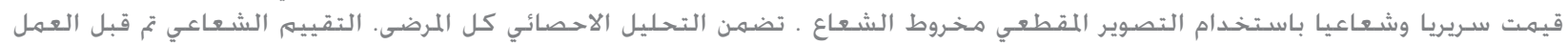

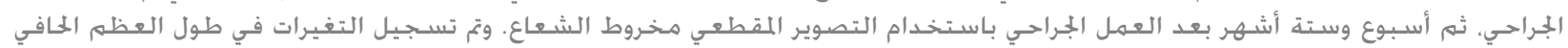

حول الغرسة السنية وكذلك كثافة العظام في كل أوجه الأسطوانة العظمية المقابلة للغرسة السنية وتقييمها من العندية الناحية الإحصائية.

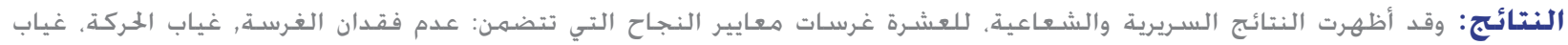
الألم، غياب العدوى والتئام العظم السنخي والتغير الإيجابي في كثافة العظام مع عدم وجود كمية كبيرة من امتصاص العظمه المافي

الخلاصة: تعتبر عملية الترقيع الثلاثية الأبعاد باستخدام طعم عظمي أسطواني الشكل من منطقة الذقن في الضروس الخلفية السفلية

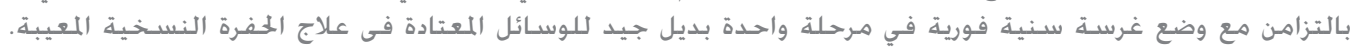

الكلمات المفتاحية: طعم عظمي أسطواني الشكل من منطقة الذقن ، وضع غرسة سنية فورية، المفرة النسخية المعيبة، التصوير المقطعي مخروط الشعاع ،تقنية ترقيع الفك. الكماح. 